\title{
Gene transfer studies in cattle
}

\author{
K. Roschlau \\ Research Centre of Animal Production, Academy of Agricultural Sciences of GDR, \\ Dummerstorf 2551, German Democratic Republic
}

Keywords: gene transfer; zygotes; cattle

\section{Introduction}

Prospects of using gene transfer in farm animals have been developed from the potential possibilities of this technology for quantitative and qualitative improvement of existing traits. On the other hand this powerful technique may create animals with completely new characteristics and make them into producers of proteins of biomedical importance.

The following aspects of the technology are currently under discussion in relation to animal improvement by genetic engineering.

- Increased growth rate

- Modification of body composition to achieve a leaner carcass

- Improvement of feed efficiency

- Increased milk production

-Modification of milk composition and secretion of foreign proteins into the milk (gene farming)

- Improved fibre production

-Altered fertility

- Improved disease resistance

\section{Methods}

In the past 5 years recombinant DNA has been successfully introduced into the germ line of rabbits, sheep and pigs (Hammer et al., 1985; Brem et al., 1985; Simons et al., 1988; Vize et al., 1988; Pursel et al., 1988), but there are only a few reports of gene transfer in cattle. The integration of injected DNA was analysed in these experiments mainly in early embryos (Lohse et al., 1985; Church et al, 1986; Roschlau et al,, 1988; Biery et al., 1988) but only a few transgenic calves have been born (Church, 1987; Roschlau et al., 1989). Gene transfer experiments in cattle are associated with a number of specific problems that differ from those for other species. One of the main difficulties is the limited access to a large number of zygotes and to an adequate number of recipients. In addition, such experiments are very expensive and time consuming because of the long generation interval. Nevertheless, cattle may be suitable for certain practical aspects of gene transfer such as 'gene farming'. We have therefore concentrated in the past few years on the development of various methods of gene transfer in cattle. The detailed results are published elsewhere (Roschlau et al,, 1989).

The established technique can be characterized as follows:

(1) Zygotes are obtained from superovulated 18-23-month-old heifers of $380-420 \mathrm{~kg}$ bodyweight. To obtain superovulation the animals are treated with PMSG and prostaglandin (Rommel et al., 1989; Roschlau et al., 1989). 
(2) The optimal time for zygote recovery in gene transfer experiments is $78-82 \mathrm{~h}$ after prostaglandin treatment.

(3) About $73 \%$ of the donor heifers react to the hormone treatment with more than 2 ovulations.

(4) An average number of 17 ovulations occurs in the ovaries of successfully superovulated heifers.

(5) After hysterectomy and flushing of the oviducts about 10 zygotes are obtained for each successfully superovulated donor.

(6) The pronuclei are visualized by centrifugation of the zygotes at $12000 \mathrm{~g}$ for $10 \mathrm{~min}$. This procedure stratifies the ooplasm and in $60 \%$ of the zygotes the pronuclei become visible by Nomarski microscopy.

(7) Foreign gene constructs are introduced into one of the two pronuclei by microinjection of 1-2 pl DNA solution.

(8) In various experiments to date with 5 different gene constructs about 900 zygotes have been injected.

(9) After gene injection and in-vitro cultivation overnight the zygotes are transferred into the oviducts of 'temporary' recipient heifers (an average of 15 zygotes per recipient) and recovered 7 to 14 days later.

(10) Rates of recovery are about $40 \%$ and are independent of the duration of the in-vivo cultivation in the oviducts. About $35 \%$ of the recovered embryos develop normally up to the morula or blastocyst stages respectively.

(11) All developed embryos recovered at an age of 14 days are analysed directly for the injected foreign DNA by dot-blot hybridization (Roschlau et al., 1988). Foreign DNA can be detected in $40 \%$ of embryos. The rate of efficiency of gene transfer (the ratio of transgenic organisms to the number of injected and transferred zygotes) calculated for preimplantation on 14-day-old embryos varies between experiments in the range of 3-6\%.

(12) The recovered 7-day-old morulae and blastocysts are transferred into the uteri of synchronous recipient heifers. In relation to the number of injected zygotes about $6 \%$ calves have been born.

(13) The total rate of efficiency of gene transfer at birth is $0.7 \%$ and so comparable with results known from other farm animals.

\section{Conclusions}

It may be said that, in our hands, we have a complete series of methods for the production of transgenic bovine embryos and calves for various purposes. In future these techniques should become more efficient, leading to a higher rate of production of transgenic calves and to decreased costs. To attain these ends we are concentrating on the following topics.

(a) The isolation of oocytes from non-stimulated slaughter-house ovaries and their in-vitro maturation and fertilization to obtain more plentiful and cheaper zygotes for experiments.

(b) The endoscopic puncture of growing follicles on the ovaries of valuable breeding cows to obtain oocytes for the production of zygotes by in-vitro fertilization.

(c) The development of long-term in-vitro cultivation methods for zygotes as an alternative for the use of temporary recipients. In preliminary experiments the co-cultivation of bovine zygotes with cumulus cells or with oviduct epithelial cells as feeder layers showed the best results.

(d) The development of methods for improvement of the integration frequency of foreign DNA in zygotes. Possibly this aim can be reached by a limited increase of the mutation rate in the recipient genome. Irradiation with ultraviolet light before transformation can double the integration frequency of DNA in somatic cells (Van Duin et al., 1985). 
(e) The establishment of an efficient integration analysis of the embryos before transplantation. This technique includes the biopsy of 1-2 single embryonic cells and their subsequent use in the polymerase chain reaction for amplification of the transgene. In this way it will be possible to transfer only transgenic embryos, thus leading to a drastic decrease in the number of necessary recipients.

(f) The introduction of an embryo cloning technique. It would be efficient to multiply an embryo after the diagnosis of its transgenic status. There are 3 possible ways for embryo cloning: (i) splitting an embryo at the morula or blastocyst stage and transplantation of half embryos; (ii) fusion of single blastomeres of a transgenic embryo with inactivated bovine oocytes and subsequent cultivation and transplantation of the fusion products; and (iii) the disaggregation of transgenic embryos at the 8-16-cell stage followed by aggregation of these blastomeres with earlier bovine embryos and transplantation of the products.

\section{References}

Biery, K.A., Bondioli, K.R. \& De Mayo, F.J. (1988) Gene transfer by pronuclear injection in the bovine. Theriogenology 29, 224, abstr.

Brem, G., Brenig, B., Goodman, H.M., Selden, R.C., Graf, F., Kruff, B., Springmann, K., Hondele, J., Meyer, J., Winnacker, E.L. \& Kräusslich, H. (1985) Production of transgenic mice, rabbits and pigs by microinjection into pronuclei. Zuchthygiene $\mathbf{2 0}$, $25 \mathrm{I}-252$.

Church R.B. (1987) Embryo manipulation and gene transfer in domestic animals. Biotechnology 5, 13-19.

Church, R.B., McRae, A. \& McWhir, J. (1986) Embryo manipulation and gene transfer in livestock production. Proc. 3rd Wld Congr. Genetics Applied to Livestock Production, Lincoln 12, 133-138.

Hammer, R.E., Pursel, V.G., Rexroad, C.E., Jr, Wall, R.J., Bolt, D.J., Ebert, K.M., Palmiter, R.D. \& Brinster, R.L. (1985) Production of transgenic rabbits, sheep and pigs by microinjection. Nature, Lond. $315,680-683$.

Lohse, J.K., Robl, J.M. \& First, N.L. (1985) Progress toward transgenic cattle. Theriogenology 23, 205, abstr.

Pursel, V.G., Miller, K.F., Pinkert, C.A., Palmiter, R.D. \& Brinster, R.L. (1988) Effect of ovum cleavage stage at microinjection on embryonic survival and gene integration in pigs. Proc. 11th Int. Congr. Anim. Reprod. \& AI, Dublin 1, 481, abstr.

Rommel, P., Hühn, R., Roschlau, K., Wiedemann, G. \& Andreewa, L. (1989) Embryotransfer als Basistechnologie für Gentransferexperimente beim Rind. Monatschr. VetMed. 44, 553-555.

Roschlau, K., Rommel, P., Roschlau, D., Schwiderski, H., Hühn, R., Kanitz, W. \& Rehbock, F. (I988) Microinjection of viral vector in bovine zygotes. Arch. Tierz 31, 3-8.

Roschlau, K., Rommel, P., Andreewa, L., Zackel, M., Roschlau, D., Zackel, B., Schwerin, M., Hühn, R. \& Gazarjan, K.G. (1989) Gene transfer experiments in cattle. J. Reprod. Fert., Suppl. 39, 153-160.

Simons, J.P., Wilmut, I., Clark, A.J., Archibald, A.L., Bishop, J.O. \& Lathe, R. (1988) Gene transfer into sheep, Bio/Technology 6, 179-183.

Van Duin, M., Westerveld, A. \& Hoeijmakers, J.H.J. (1985) UV stimulation of DNA-mediated transformation of human cells. Molec. cell. Biol. 5, 734-74I.

Vize, P.D., Michalska, A.E., Ashman, R., Lloyd, B., Stone, B.A., Quinn, P., Wells, J.R.E. \& Seamark, R.F. (1988) Introduction of a porcine growth hormone fusion gene into transgenic pigs promotes growth. J. Cell Sci. 90, 295-300. 